\title{
Neutralization of Glucagon by Antiserum as a Tool in Glucagon Physiology
}

\author{
LACK OF DEPRESSION OF BASAL BLOOD GLUCOSE AFTER ANTISERUM \\ TREATMENT IN RATS
}

\author{
J. J. Holst, H. Galbo, and E. A. Richter, Department of Clinical Chemistry, \\ Bispebjerg Hospital, and the Institute of Medical Physiology B, University of \\ Copenhagen, Copenhagen, Denmark
}

\begin{abstract}
A B S TRACT The method of producing experimental glucagon deficiency by administration of glucagon antiserum was evaluated in rats. A pool of antisera was prepared, the affinity of which exceeded that of the glucagon receptors of liver cell membranes, whereas the binding capacity of the volume used amounted to more than one-third of the total glucagon content in the rat pancreas. That rapid, extensive, and lasting neutralization of glucagon had taken place after antiserum treatment was indicated by the following findings: When examined more than $1 \mathrm{~h}$ after the injection and after $60 \mathrm{~min}$ of exercise-stimulated glucagon production, all rats had excess free antibodies in plasma. The concentration of free glucagon was lowered to one-third of the concentration in control rats; at $37^{\circ} \mathrm{C}$ plasma samples could bind $25 \%$ of additional 300 $\mathrm{pmol} /$ liter of glucagon in $10 \mathrm{~s}$, and $69 \%$ in $120 \mathrm{~s}$; the glycemic response to exogenous glucagon was abolished. Antiserum treatment, however, had no effect on blood glucose in rats fasted for 3 and $10 \mathrm{~h}$, in chemically sympathectomized and adrenomedullectomized rats, and in 48-h-fasted, acutely adrenalectomized rats. The antiserum was found to contain 460 $\mathrm{nmol} /$ liter of antibody-bound glucagon, originating in the rabbit in which the antiserum was raised. However, antibody preparations from which the bound glucagon had been effectively removed were equally ineffective in lowering the basal blood glucose in rats, although in three-fourths of the rats the concentra-
\end{abstract}

E. Richter was a Medical Student Research Trainee supported by a grant from the Johann and Hanne Weimann, $f$. Seedorff Foundation.

Received for publication 15 November 1977 and in revised form 20 February 1978. tion of free glucagon was lowered beyond detection limit.

The data indicate that the absolute concentration of glucagon in plasma is of minor importance for the maintenance of basal blood glucose in the rat.

\section{INTRODUCTION}

The hyperglycemic effect of insulin deficiency produced by administration of insulin antiserum is well known $(1,2)$. Similar experiments with antisera against glucagon have been less illustrative.

An acute blood glucose lowering effect of glucagon antiserum was demonstrated in 48-h-fasted adrenalectomized rats (3), and preincubation with antibodies abolished the hyperglycemic effect of glucagon in vitro and in vivo (4). Antiserum, however, did not affect blood glucose concentrations in fed or postabsorptive animals $(3,5,6)$. Recent studies of glucagon deficiency induced by somatostatin have suggested that basal glucagon secretion is at least partly responsible for maintenance of euglycemia, because the glucose lowering effect of somatostatin is correlated with glucagon suppression and may be reversed by exogenous glucagon (7-11). The variable effect of glucagon antiserum administration could be the result of incomplete neutralization of circulating glucagon (5). We therefore studied the neutralization of endogenous and exogenous glucagon in antiserumtreated rats, as well as the effect of antiserum on basal blood glucose, after fasting of various periods of time, and after procedures designed to eliminate adrenergic antihypoglycemic mechanisms. Some of the experiments were performed in exercising rats to 
study the effectiveness of neutralization during increased glucagon production (12).

\section{METHODS}

Male Wistar rats weighing 240-260 $\mathrm{g}$ were used for the experiments. Secretion of glucagon was stimulated by forcing the rats to swim (with a tail weight, $2 \%$ of body weight), for $60 \mathrm{~min}$ in water maintained at $33-34^{\circ} \mathrm{C}$. Blood samples were obtained by cardiac puncture while the rats were briefly anesthetized with ether. The cardiac cannula was also used for the injection of glucagon antiserum or control serum. Blood was collected into chilled heparinized syringes which also contained aprotinin (Trasylol, the Bayer Co., Sterling Drug Inc., Rensselaer, N. Y.) $500 \mathrm{kIU} / \mathrm{ml}$ blood. Blood glucose, plasma glucagon, plasma insulin, serum glycerol, and serum nonesterified fatty acid concentrations were determined as previously described $(12,13)$. Samples of liver were stored at $-80^{\circ} \mathrm{C}$ until the glycogen content was determined by a hexokinase method after hydrolysis (14); the glycogen values are expressed as millimoles of glucose per kilogram wet tissue. The detection limit of the glucagon assay was $4 \mathrm{pmol} / \mathrm{liter}$ and intra- and interassay coefficients of variation 6 and $16 \%$, respectively, at $25 \mathrm{pmol} / \mathrm{liter}$. Standards were highly purified porcine glucagon (Novo Research Institute, Copenhagen, Denmark), which was also used for injection because porcine and rat glucagons have identical amino acid compositions (15). The antibody used (4317) is directed against a part of the C-terminal sequence of the glucagon molecule and does not cross-react with any of the gut glucagons (16). The assay system was essentially that of Heding (17), including extraction of plasma with $61 \%$ ethanol before assay. Dilution curves of (extracted) rat plasma were parallel to the standard curves. Monoiodinated ${ }^{125} \mathrm{I}$-glucagon (18) was purchased from the Novo Research Institute. The specific activity was approximately $730 \mathrm{Ci} / \mathrm{mmol}$. The stock tracer solution of glucagon was $45 \mathrm{nmol} / \mathrm{liter}$. The detection limit of the insulin assay, which was performed according to the principles of Albano et al. (19) was $0.5 \mathrm{pmol} / \mathrm{liter}$, and the intra- and interassay coefficients of variation 5 and $10 \%$, respectively, at $40 \mathrm{pmol} / \mathrm{liter}$. Standards were human monocomponent insulin (Novo Research Institute), but the antiserum used cross-reacted strongly with rat insulin (a gift from L. G. Heding, Novo Research Institute), and dilution curves of rat plasma paralleled roughly the standard curves.

Determination of free glucagon. To $0.5 \mathrm{ml}$ rat plasma, ethanol was added to a final concentration of $80 \%$ ( $\mathrm{vol} / \mathrm{vol})$. After $30 \mathrm{~min}$ centrifugation, the supernate was decanted and evaporated to dryness in a vacuum desiccator. The samples were then reconstituted to the original volume with assay buffer (13) and assayed for glucagon. With $80 \%$ ethanol $>70 \%$ of the free glucagon is recovered, whereas antibody-bound glucagon is effectively precipitated (17) Furthermore, the precipitate does not leak off glucagon (17).

Determination of total (antibody-bound + free) glucagon. To $0.5 \mathrm{ml}$ rat plasma, $\mathrm{HCl}$ ( $1.0 \mathrm{~mol} /$ liter) was added to $\mathrm{pH} 2.5$, and the tubes were left at room temperature for $15 \mathrm{~min}$. Ethanol was added to a final concentration of $61 \%$ ( $\mathrm{vol} / \mathrm{vol})$, and the $\mathrm{pH}$ was brought to 8 with $25 \%$ ammonia. The precipitate was removed by centrifugation and the supernate evaporated to dryness, reconstituted in assay buffer, and assayed for glucagon. In this way a reliable estimate of the total (antibody-bound + free) glucagon concentration was obtained $(17,20)$.

Antisera to glucagon for injection were produced as previously described (13), and a pool of antisera was analyzed for titer, avidity, and binding capacity $(13,21)$. Serum from normal, nonimmunized rabbits was used for control experiments. Statistical evaluation of the data was performed with the use of the Mann-Whitney U-test, the Wilcoxon signed rank test for paired data, and Friedman's two-way analysis of variance (22). However, for the sake of convenience, the data are presented as mean $\pm S E M$. Differences resulting in $P$ values $<0.05$ were considered significant.

\section{RESULTS}

1. The glucagon antiserum pool. The titer of the pool (i.e., the dilution of the antiserum that bound approximately $50 \%$ of $10 \mathrm{fmol}$ labeled glucagon under standard assay conditions [13]) was 1:40,000. The antiserum thus diluted was incubated with increasing amounts of unlabeled glucagon and $10 \mathrm{fmol}$ labeled glucagon for 3 days in a volume of $0.5 \mathrm{ml}$ and free and bound hormone separated by ethanol precipitation. The addition of $10 \mathrm{pmol} /$ liter glucagon significantly lowered the binding of the label $(8 \%$ of the binding without unlabeled glucagon, $P<0.005)$. From the binding data, a Scatchard plot (21) was constructed (Fig. 1).

The nonlinear shape of the Scatchard plot indicated the presence of more than one class of glucagon binding sites. The experimental curve was graphically resolved into two linear components according to Rosenthal (23), and a reasonable fit was reached. Accordingly, the pool may be regarded as consisting of one class of

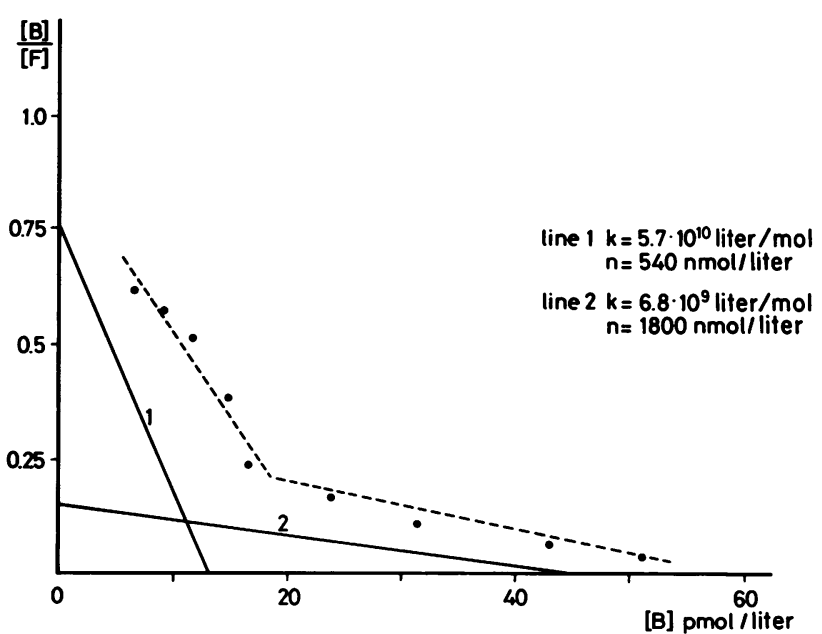

FIGURE 1 Affinity and binding capacity of antiserum. A pool of glucagon antisera was incubated with increasing amounts of glucagon $+10 \mathrm{fmol}$ labeled glucagon. After 3 days at $4^{\circ} \mathrm{C}$ free and bound were separated using ethanol precipitation. A Scatchard plot (20) was constructed from the binding data according to the formula $B / F=K(n-B)$, where $B$ is the concentration of bound hormone, $F$ the concentration of free hormone, $K$ the equilibrium constant, and $n$ the total concentration of antibody binding sites. A graphical resolution into two linear components was then performed according to Rosenthal (22). The binding constants of the two resulting classes of antibodies are given in the figure. 
TABLE I

Plasma Concentrations of Free and Antibody-Bound Glucagon in Control and Antiserum-Treated Rats after Exercise

\begin{tabular}{lccc}
\hline Treatment & Total glucagon & $\begin{array}{c}\text { Free } \\
\text { glucagon }\end{array}$ & $\begin{array}{c}\text { Binding of } \\
\text { 125I-glucagon }\end{array}$ \\
\hline & $p m o l l$ liter & $p$ mol/liter & $\%$ \\
Control serum & $80 \pm 17$ & $60 \pm 15$ & $15.9 \pm 0.43$ \\
& $(4)$ & $(6)$ & $(10)$ \\
Glucagon & $10,000 \pm 1,001^{*}$ & $24 \pm 2.6^{*}$ & $43.4 \pm 0.66^{*}$ \\
antiserum & $(4)$ & $(6)$ & $(10)$ \\
\hline
\end{tabular}

Eight rats received either antiserum or nonimmune serum and were exercised for $60 \mathrm{~min}$; then blood was drawn for determination of the total glucagon concentrations by means of an acid-ethanol technique. Another 12 rats were treated similarly and their plasma was analyzed for free glucagon after extraction with ethanol (final concentration $80 \%$ [vol/vol]). Results are presented as mean \pm SEM. Number of experiments in parentheses. Excess antibody was demonstrated by incubation of $300 \mu$ l plasma, diluted 1,500 times with $10 \mathrm{fmol}{ }^{125} \mathrm{I}$-glucagon. After separation the fraction of bound hormone was determined as described in the text.

* Significantly different from controls.

antibodies with an equilibrium constant of $5.7 \times 10^{10}$ liters/mol and a binding capacity of $540 \mathrm{nmol} / \mathrm{liter}$, and another class with an equilibrium constant of 6.8 $\times 10^{9}$ liters $/ \mathrm{mol}$ and a binding capacity of $1,800 \mathrm{nmol} /$ liter.

2. Determination of free and antibody-bound glucagon in antiserum-treated exercised rats (Table I). 12 rats were fasted for $1 \mathrm{~h}$ and then injected with $0.5 \mathrm{ml}$ of either control serum ( 6 rats) or undiluted antiserum (6 rats). After $15 \mathrm{~min}$ rest they exercised for $60 \mathrm{~min}$ with $2 \%$ tail weight. Then, as quickly as possible, 2 $\mathrm{ml}$ cardiac blood was poured into iced Trasylol-containing heparinized tubes and centrifuged in the cold. Plasma was assayed for free glucagon. The results are shown in Table I. Antiserum treatment significantly lowered the concentration of free glucagon ( $P$ $=0.025$ ).

Another eight rats were treated similarly (four control and four antiserum rats). After exercise cardiac blood was drawn into chilled heparinized Trasylolcontaining tubes and centrifuged in the cold. The plasma was assayed for total glucagon (antibody-bound + free). The results appear in Table I. Although the total glucagon concentrations in the control rats were similar to the concentrations of free glucagon obtained in the foregoing series, the concentrations in the antiserum group were 125 times higher $(P=0.014)$. Finally, plasma from both groups of rats was examined for excess antibodies after exercise by incubating plasma at various dilutions with labeled glucagon, separating bound and free, and counting both fractions. The titer (the dilution, which would bind approximately $50 \%$ of the label) was then determined. All antiserum-treated rats had titers of approximately $1: 1,500$, corresponding to an excess binding capacity of the postexercise rat plasma of $20 \mathrm{nmol} /$ liter or, if corrected for the nonspecific binding of the control plasma (24) (Table I), $10.8 \mathrm{nmol} /$ liter.

3. Kinetics of binding at $37^{\circ} \mathrm{C}$. Eight 1-h-fasted rats (four controls and four antiserum-treated) were forced to swim. Plasma obtained after exercise was heated to $37^{\circ} \mathrm{C}$ and $0.5 \mathrm{ml}$ was incubated with 140 fmol glucagon $+10 \mathrm{fmol}$ labeled glucagon (a total of $0.15 \mathrm{pmol}$ ) prepared in a volume of $50 \mu \mathrm{l}$ of buffer and preheated to $37^{\circ} \mathrm{C}$. Incubation lasted for $10-120$ as indicated in Table II. All handling of tubes was performed as quickly as possible, adequate mixing was ensured with a mixing device (CycloMixer, Clay Adams, Div. of Becton, Dickinson \& Co., Parsippany, N. J.) and incubation took place - apart from the mixing time-at $37^{\circ} \mathrm{C}$ in a thermostated water bath. The reaction was terminated by the addition of ethanol to a final concentration of $80 \%$ ( $\mathrm{vol} / \mathrm{vol}$ ) (to ensure com-

TABLE II

Time-course of Binding of Added Glucagon (300 pmol/liter) to Antibodies in Plasma from Passively Immunized Rats at $37^{\circ} \mathrm{C}$

\begin{tabular}{lcccc}
\hline & \multicolumn{5}{c}{ Incubation time } \\
\cline { 2 - 5 } Group of rats & 10 & 30 & 60 & 120 \\
\hline & & & $s$ & \\
$\begin{array}{c}\text { Control } \\
\text { serum, } \\
n=4 \\
\begin{array}{c}\text { Undiluted } \\
\text { antiserum, } \\
n=4\end{array}\end{array}$ & $27.1 \pm 0.9$ & $26.7 \pm 1.1$ & $27.3 \pm 1.3$ & $27.8 \pm 1.7$ \\
$\begin{array}{c}\text { Antiserum, } \\
n=4\end{array}$ & - & - & - & $94.6 \pm 0.4$ \\
$\begin{array}{c}\text { Antiserum, } \\
\text { corrected } \\
\text { values }\end{array}$ & 25.5 & 46.5 & 51.3 & 69.2 \\
\hline
\end{tabular}

Precipitation of ${ }^{125} \mathrm{I}$-glucagon (\%) added as tracer. Four rats received antiserum and four received nonimmune serum intracardially and were exercised for $60 \mathrm{~min}$. Then blood was drawn and $0.5 \mathrm{ml}$ plasma incubated with $140 \mathrm{fmol}$ glucagon and $10 \mathrm{fmol}{ }^{125} \mathrm{I}$-glucagon at $37^{\circ} \mathrm{C}$ for the time indicated. The reaction was stopped with ethanol, and precipitate and supernate counted for radioactivity. All incubations were made in duplicate. Results of first three lines are presented as radioactivity in precipitate in percent of total (mean \pm SEM). The results in the last line represent the calculated binding of glucagon (in percent) as corrected for incomplete immunoreactivity of tracer (second line) and unspecified binding (first line). 
plete precipitation of antibody-bound glucagon), thorough mixing, and centrifugation for $30 \mathrm{~min}$. Both supernate and precipitate were counted. All incubations were performed in duplicate. In a control experiment undiluted rabbit glucagon antiserum instead of rat plasma was incubated in the same way for $120 \mathrm{~s}$.

The raw binding data are presented in the upper three lines of Table II. In extreme antibody excess, $95 \%$ of the labeled glucagon was precipitable. The nonspecific binding of the control plasma (27\%) may be regarded as "damage," and the binding data probably should be corrected accordingly (24). The corrected values appear in the fourth line.

Even after $10 \mathrm{~s}$ a substantial part of the added glucagon was bound by the antibodies with free binding sites in the plasma of the antiserum-treated rats $(P$ $=0.014)$, and binding increased throughout the incubation period.

4. Neutralization of exogenous glucagon. 23, 3-hfasted rats $(11$ control rats and 12 antiserum-treated rats) rested for $60 \mathrm{~min}$ after intracardial injection of serum or antiserum. Then $0.5 \mathrm{ml}$ blood was drawn for glucose determination, and glucagon in a dose of 30 $\mathrm{pmol} / \mathrm{kg}$ dissolved in $0.3 \mathrm{ml} 0.15 \mathrm{~mol} /$ liter $\mathrm{NaCl}$ containing $0.1 \%$ human serum albumin (Behring-Werke AG, Marburg/Lahn, West Germany) was injected. After another $30 \mathrm{~min}$ the rats were exsanguinated and a liver specimen removed for glycogen determination. The results of assay for metabolites and hormones appear in Table III. The glucagon injection caused a significant increase in blood glucose concentration after $30 \mathrm{~min}$ in control rats, whereas no significant change was found in the antiserum-treated rats. Plasma insulin concentration was significantly higher in the control group, and the concentration of glycerol was lower, whereas concentrations of free fatty acids and liver glycogen did not differ significantly in control rats compared to antiserum-treated rats.

5. Effect of antiserum on blood glucose concentration (Tables IV and V). (a) 30 rats were fasted for $3 \mathrm{~h} .15$ rats then received $0.5 \mathrm{ml}$ antiserum and 15 rats received $0.5 \mathrm{ml}$ control serum. Blood glucose was determined before and $75 \mathrm{~min}$ after the administration. Blood glucose rose slightly in both groups, but the changes were not significantly different.

(b) 12 rats fasted for $10 \mathrm{~h}$. Six rats received antiserum and six rats received control serum. Glucose concentrations tended to increase in the antiserum group and to decrease in the control group. However, the changes were not significantly different.

(c) In 17 rats, chemical sympathectomy was performed by the administration of 6-hydroxy-dopamine (25) and adrenomedullectomy by electrocoagulation. 2 wk later eight rats received antiserum and nine rats received control serum. A further 16 rats were shamoperated and injected with saline instead of 6-hydroxydopamine. Eight were given antiserum, and eight control serum. All rats were fasted for $3 \mathrm{~h}$ before the experiment. After 75 min a small rise in blood glucose was noted in the control group of sympathectomized rats, and a slight fall in the antiserum group. The changes were, however, insignificant. A similar pattern was found in the sham-operated group.

(d) 17 rats were fasted for $48 \mathrm{~h} .60 \mathrm{~min}$ before the injection of antiserum or control serum they were anesthetized with pentothal sodium intraperitoneally and adrenalectomized. A small polyethylene catheter was inserted into a carotid artery for blood sampling. After three base-line samples, nine rats received antiserum and eight rats control serum through the catheters. Blood glucose was then measured for $60 \mathrm{~min}$ at the times indicated in Table $\mathrm{V}$. There were no significant

TABLE III

Neutralization of the Effects of Exogenous Glucagon by Glucagon Antiserum

\begin{tabular}{|c|c|c|c|c|c|c|c|c|}
\hline Treatment & $\begin{array}{l}\text { Glucose } \\
\text { at } 60 \mathrm{~min}\end{array}$ & $\begin{array}{l}\text { Glucose } \\
\text { at } 90 \mathrm{~min}\end{array}$ & $\begin{array}{l}\text { NEFA* } \\
\text { at } 90 \mathrm{~min}\end{array}$ & $\begin{array}{l}\text { Glycerol } \\
\text { at } 90 \mathrm{~min}\end{array}$ & $\begin{array}{l}\text { Insulin } \\
\text { at } 60 \mathrm{~min}\end{array}$ & $\begin{array}{l}\text { Insulin } \\
\text { at } 90 \mathrm{~min}\end{array}$ & $\begin{array}{l}\text { Glucagon } \\
\text { at } 90 \mathrm{~min}\end{array}$ & $\begin{array}{c}\text { Liver } \\
\text { glycogen }\end{array}$ \\
\hline & mmollliter & mmollliter & mmol/liter & 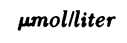 & pmol/liter & pmollliter & pmollliter & $\mathrm{mmol} / \mathrm{kg}$ \\
\hline $\begin{array}{r}\text { Control } \\
\text { serum }\end{array}$ & $\begin{array}{c}7.4 \pm 0.78 \\
(11)\end{array}$ & $\begin{array}{c}9.5 \pm 0.90 \ddagger \\
(11)\end{array}$ & $\begin{array}{c}0.517 \pm 0.041 \\
(9)\end{array}$ & $\begin{array}{c}190 \pm 12 \\
(9)\end{array}$ & $\begin{array}{c}\text { Not } \\
\text { measured }\end{array}$ & $\begin{array}{r}26 \pm 4 \\
(9)\end{array}$ & $\begin{array}{c}86 \pm 6.9 \\
(9)\end{array}$ & $\begin{array}{c}164 \pm 26 \\
(11)\end{array}$ \\
\hline $\begin{array}{l}\text { Glucagon } \\
\text { antiserum }\end{array}$ & $\begin{array}{c}7.0 \pm 0.31 \\
(11)\end{array}$ & $\begin{array}{c}7.7 \pm 0.46 \S \\
(11)\end{array}$ & $\begin{array}{c}0.650 \pm 0.051 \\
(12)\end{array}$ & $\begin{array}{c}234 \pm 12^{\prime \prime} \\
(12)\end{array}$ & $\begin{array}{c}12 \pm 2 \\
(12)\end{array}$ & $\begin{array}{c}14 \pm 2^{\prime \prime} \\
(12)\end{array}$ & $\begin{array}{l}\text { Excess anti- } \\
\text { body; titer } \\
>1: 1,500\end{array}$ & $\begin{array}{c}159 \pm 22 \\
(12)\end{array}$ \\
\hline
\end{tabular}

Rats received either antiserum or nonimmune serum intracardially. After 60 min blood was drawn by cardiac puncture, and glucagon, $30 \mathrm{pmol} / \mathrm{kg}$, was injected. After another $30 \mathrm{~min}$ the rats were exsanguinated and a liver biopsy removed. Results are presented as mean $\pm \mathrm{SEM}$, and the number of experiments is indicated in parentheses.

* Nonesterified fatty acid concentrations.

\$ Significantly different from the 60 -min value $(P=0.002)$.

$\$ 60$ to 90 -min changes significantly different from controls $(P<0.05)$.

"Significantly different from controls $(P<0.02)$. 
TABLE IV

Effect of Glucagon Antiserum on Blood Glucose Concentration (millimoles/liter) in Rats

\begin{tabular}{|c|c|c|c|c|c|c|}
\hline \multirow[b]{2}{*}{ Group of rats } & \multicolumn{3}{|c|}{ Glucagon antiserum } & \multicolumn{3}{|c|}{ Control serum } \\
\hline & Before & 75 min after & Change & Before & 75 min after & Change \\
\hline 3-h fast & $\begin{array}{l}6.3 \pm 0.40 \\
\quad(15)\end{array}$ & $\begin{array}{l}6.8 \pm 0.26 \\
\quad(15)\end{array}$ & $0.55 \pm 0.31$ & $\begin{array}{l}6.8 \pm 0.39 \\
\quad(15)\end{array}$ & $\begin{array}{l}7.7 \pm 0.34 \\
(15)\end{array}$ & $0.86 \pm 0.4$ \\
\hline 10-h fast & $\begin{array}{c}6.1 \pm 0.43 \\
(6)\end{array}$ & $\begin{array}{c}6.7 \pm 0.43 \\
(6)\end{array}$ & $0.59 \pm 0.65$ & $\begin{array}{c}6.0 \pm 0.32 \\
(6)\end{array}$ & $\begin{array}{c}5.5 \pm 0.38 \\
(6)\end{array}$ & $-0.48 \pm 0.4$ \\
\hline \multicolumn{7}{|l|}{ 3-h fast } \\
\hline $\begin{array}{l}\text { + sympathectomy } \\
\text { + adrenomedullectomy }\end{array}$ & $\begin{array}{c}5.9 \pm 0.18 \\
(8)\end{array}$ & $\begin{array}{c}5.8 \pm 0.12 \\
(8)\end{array}$ & $-0.13 \pm 0.14$ & $\begin{array}{c}5.8 \pm 0.13 \\
(9)\end{array}$ & $\begin{array}{c}6.2 \pm 0.19 \\
(9)\end{array}$ & $0.40 \pm 0.2$ \\
\hline $\begin{array}{l}\text { 3-h fast } \\
\quad+\text { sham-operated } \\
\quad+\text { sham-injected }\end{array}$ & $\begin{array}{c}5.8 \pm 0.12 \\
(8)\end{array}$ & $\begin{array}{c}5.7 \pm 0.27 \\
(8)\end{array}$ & $-0.05 \pm 0.23$ & $\begin{array}{c}5.8 \pm 0.15 \\
(8)\end{array}$ & $\begin{array}{c}6.1 \pm 0.42 \\
(8)\end{array}$ & $0.34 \pm 0.4$ \\
\hline
\end{tabular}

All rats received $0.5 \mathrm{ml}$ glucagon antiserum or nonimmune serum intracardially. After 75 min blood was drawn by cardiac puncture and analyzed for glucose. The results are presented as mean $\pm \mathrm{SEM}$. Number of experiments is indicated in parentheses.

changes in either group. $60 \mathrm{~min}$ after the injection, four rats (two controls and two antiserum-treated) were given glucagon as above (section 4) and blood glucose followed for $45 \mathrm{~min}$. Blood glucose concentrations remained unchanged, however.

6. Antibody-bound glucagon, originating in the immunized rabbits (Table VI). The very high concentrations of bound glucagon in the plasma of the antiserum-treated rats gave rise to the suspicion that some of the bound glucagon might originate in the rabbit in which the antiserum was raised. We therefore determined the concentration of bound glucagon in the antiserum pool, applying the previously described technique to the undiluted antiserum. The total concentration of glucagon was $460 \mathrm{nmol} / \mathrm{liter}$ (mean of triplicate determination). That this very high value was not due to technical errors in the determination of antibody-bound glucagon was evidenced by a gel filtration on Sephadex G 50 SF (Pharmacia Fine Chemicals, Piscataway, N. J.) of the solution of liberated glucagon which had elution characteristics similar to marker glucagon; and the recovery of gluca- gon immunoreactivity from the column corresponded well to the amount of immunoreactive glucagon that had been applied. In two experiments normal rabbit serum was investigated similarly, but we found no indication of glucagon binding by ethanol-precipitable proteins in the rabbit serum. This is in agreement with our finding that the total concentration of glucagon in control-serum treated rats differed only slightly from the concentration of free glucagon (Table I).

Because the antiserum pool was now exhausted, a new antiserum, 371-VII, was selected. The titer was $1: 400,000$ and the binding capacity $3,800 \mathrm{nmol} / \mathrm{liter}$. The antiserum was saturated with sodium sulfate, and the precipitate resuspended in glycine buffer, 0.4 $\mathrm{mol} / \mathrm{liter}, \mathrm{pH} \mathrm{2.5}$, containing in addition $3 \mathrm{~mol} / \mathrm{liter}$ guanidine HCL (Ultra Pure, Schwarz/Mann Div., Becton Dickinson \& Co., Orangeburg, N. Y.). The solution was left overnight at room temperature and applied the next day to a $40 \times 200-\mathrm{mm}$ column of Ultrogel AcA 44 (LKB, Industrie Biologique Française, France) equilibrated with $0.2 \mathrm{~mol} /$ liter glycine buffer, $\mathrm{pH}$ 2.5. The glucagon antibodies in the effluent were

TABLE V

Effect of Glucagon Antiserum on Blood Glucose Levels (millimoles/liter) in 48-h-Fasted, Acutely Adrenalectomized Rats

\begin{tabular}{lccccccr}
\hline & \multicolumn{7}{c}{ Time after injection (min) } \\
\cline { 2 - 8 } \multicolumn{1}{c}{ Group of rats } & -15 & -5 & 0 & 15 & 30 & 45 & 60 \\
\hline Control serum, $n=8$ & $3.09 \pm 0.17$ & $3.15 \pm 0.14$ & $3.26 \pm 0.18$ & $3.35 \pm 0.15$ & $3.25 \pm 0.16$ & $3.28 \pm 0.22$ & $3.14 \pm 0.20$ \\
Antiserum , $n=9$ & $2.90 \pm 0.17$ & $2.92 \pm 0.17$ & $2.83 \pm 0.15$ & $2.86 \pm 0.14$ & $2.77 \pm 0.12$ & $2.68 \pm 0.12$ & $2.71 \pm 0.11$ \\
\hline
\end{tabular}

17 rats were fasted for $48 \mathrm{~h}$ and acutely adrenalectomized. Blood samples obtained from a catheter in a carotid artery were analyzed for glucose. At $0 \mathrm{~min}$ nine rats received antiserum and eight rats nonimmune serum. Blood glucose concentrations were followed for $60 \mathrm{~min}$. Data are presented as mean $\pm \mathrm{SEM}$. 
recovered after they had been identified by incubating $2 \mathrm{ul}$ of the eluted fractions with ${ }^{125}$ I-labeled glucagon dissolved in $1.0 \mathrm{ml}$ assay buffer for $1 \mathrm{~h}$, separating free and bound with ethanol, and counting the precipitates. The $\mathrm{pH}$ of the collected fractions was adjusted to 5.0 and the globulins salted out with sodium sulfate. The precipitate was redissolved in $0.2 \mathrm{~mol} /$ liter glycine buffer, $\mathrm{pH} 2.5$, containing in addition $3 \mathrm{~mol} /$ liter urea (Aristar, BDH Chemicals Ltd., Poole, Eng.) and the pH brought to 5.0. The titer of the antibody solution (brought to the original volume of the antiserum) was now $1: 100,000$. The concentration of bound glucagon had fallen from $716 \mathrm{nmol} / \mathrm{liter}$ of the original antiserum to $14 \mathrm{nmol} /$ liter. Serum from a normal rabbit was treated in parallel with the antiserum. These preparations were then administered to rats (stage I).

12 rats fasted for $10 \mathrm{~h}$. Five rats received $1.0 \mathrm{ml}$ antibody solution, corresponding to $0.25 \mathrm{ml}$ of the original antiserum, and six rats received the control preparation. Blood for glucose determination was obtained just before and $75 \mathrm{~min}$ after the injections. The results appear in Table VI. Blood glucose concentrations were significantly elevated in the control group, but remained unchanged in the antibodytreated group. Because the urea- and glycine-containing solution of control gamma globulins lead to such pronounced effects on the blood glucose concentrations of the control rats, and because some bound glucagon still remained antibody-bound in the gluca- gon-antibody preparation, we purified further the globulin preparations and continued our efforts to strip off the bound glucagon. The glucagon antibody and the control preparation were again adjusted to $\mathrm{pH} 2.5$ with $\mathrm{HCl}$ and applied to the Ultrogel column, which this time was equilibrated and eluted with $0.1 \mathrm{~mol} / \mathrm{liter}$ glycine buffer, $\mathrm{pH}$ 2.5. The antibody-containing fractions were collected, adjusted to $\mathrm{pH} 7$, and precipitated with sodium sulfate. The precipitates were dissolved in saline, in a volume corresponding to the original volume of the serum. The control solution contained no detectable antibodies to glucagon and no detectable bound glucagon. The titer of the antibody solution was 1:100,000, and the equilibrium constant and binding capacity determined as described above (section 1) were $5.5 \times 10^{10} \mathrm{liter} / \mathrm{mol}$ and $1,600 \mathrm{nmol} /$ liter (Fig. 2). Antibody-bound glucagon was no longer detectable. These preparations were then used for further studies in rats (stage II). 24 rats were fasted for $10 \mathrm{~h} .6$ rats received $1.0 \mathrm{ml}$ saline, 10 rats received control gamma globulin solution, and 8 rats received $1.0 \mathrm{ml}$ antibody solution, corresponding to $1.0 \mathrm{ml}$ of the original antiserum. Blood for glucose determination was drawn before (all rats), and 20 (16 rats) and $60 \mathrm{~min}$ (8 rats) after the injection. At 20 and $60 \mathrm{~min}$ blood samples were also taken for the determination of the concentration of free glucagon in plasma, and determination of titer of glucagon antibodies in plasma. The results appear in Table VI. All antibody-treated rats had titers of approxi-

TABLE VI

The Effect of Antigen-Stripped Glucagon Antibodies on Blood Glucose and Plasma Glucagon in Rats

\begin{tabular}{|c|c|c|c|c|}
\hline Treatment and time of sampling & Glucose & $\begin{array}{c}\text { Change of glucose } \\
\text { from preinjection } \\
\text { values }\end{array}$ & Free glucagon & $\begin{array}{l}\text { Binding of }{ }^{125} \mathrm{I}- \\
\text { glucagon (dilution of } \\
\text { plasma } 1: 6,000 \text { ) }\end{array}$ \\
\hline & mmol/iter & mmol/hiter & pmolliter & $\%$ \\
\hline 75 min after control gamma globulins, stage $I, n=6$ & $10.38 \pm 1.59$ & $3.50 \pm 1.4^{*}$ & - & - \\
\hline 75 min after stripped antiserum, stage $I, n=5$ & $6.90 \pm 0.16$ & $-0.12 \pm 0.25$ & - & - \\
\hline 20 min after saline, $n=6$ & $7.28 \pm 0.26$ & $1.55 \pm 0.33^{*}$ & $59 \pm 6.2$ & $13.28 \pm 0.20$ \\
\hline 20 min after control gamma globulins, stage II, $n=6$ & $8.36 \pm 0.28$ & $2.74 \pm 0.21 *$ & $59 \pm 10.8$ & $15.68 \pm 2.40$ \\
\hline 20 min after stripped antibody, stage II, $n=4$ & $6.68 \pm 0.33$ & $1.14 \pm 0.44$ & ND,ND,ND,24\$§ & $49.34 \pm 4.75 \ddagger$ \\
\hline 60 min after control gamma globulin, Stage II, $n=4$ & $7.40 \pm 0.81$ & $1.37 \pm 0.59^{\prime \prime}$ & $60 \pm 7.6$ & $15.35 \pm 0.86$ \\
\hline 60 min after stripped antibody, stage II, $n=4$ & $5.60 \pm 0.13$ & $0.18 \pm 0.23$ & $\mathrm{ND}, \mathrm{ND}, \mathrm{ND}, 44 \S \pi$ & $43.30 \pm 2.64 \ddagger$ \\
\hline
\end{tabular}

35 rats fasted for $10 \mathrm{~h}$, and blood samples were taken for glucose determination. Stripped antiserum and control serum were prepared as described in the text. Five rats received $1.0 \mathrm{ml}$ partially stripped antibody solution (containing 14 nmol/liter bound glucagon) and six rats the corresponding control preparation (stage I). Six rats received $1.0 \mathrm{ml}$ saline, 8 rats received $1.0 \mathrm{ml}$ stripped antibody solution without detectable bound glucagon (stage II), and 10 rats the corresponding control preparation. Blood samples for determination of glucose, free glucagon, and antibody titer were taken at the times indicated in the table. Data are presented as mean \pm SEM.

ND, not detectable ( $<4 \mathrm{pmol} / \mathrm{liter})$.

* Significant changes $(P=0.001)$.

\$ Significantly different from controls $(P=0.005)$.

$\$$ Individual values shown.

"Significant changes $(P=0.014)$.

ๆ Significantly different from controls $(P=0.029)$. 
mately 1:6,000. Glucose concentrations increased slightly, but significantly, in control animals (saline and globulin-injected), whereas glucose concentrations were unchanged in the antibody-treated rats. When comparing the changes in blood glucose, antiserum-treated animals differed significantly from control-serum treated $(P=0.009)$. The concentrations of free glucagon averaged 59-60 pmol/liter in saline or globulin-injected animals, but were undetectable in six of the antiserum-treated rats. When comparing the groups, the concentrations of free glucagon were significantly lower in the antibody-treated rats than in the control groups $(P<0.001)$.

\section{DISCUSSION}

The present study was aimed at the solution of three problems: (a) Can it be demonstrated by immunochemical methods that the administration of potent glucagon antisera to rats will lead to neutralization of endogenously produced glucagon to such an extent that the technique can be used for the experimental production of glucagon deficiency? $(b)$ If so, what is the effect of neutralizing the endogenous glucagon on the basal concentrations of glucose in blood? (c) Will the removal from the antisera of antibody-bound glucagon, originating in the rabbit in which the antiserum was produced, lead to a more efficient neutralization?

The following results indicate that an extensive binding and neutralization of endogenously pro-

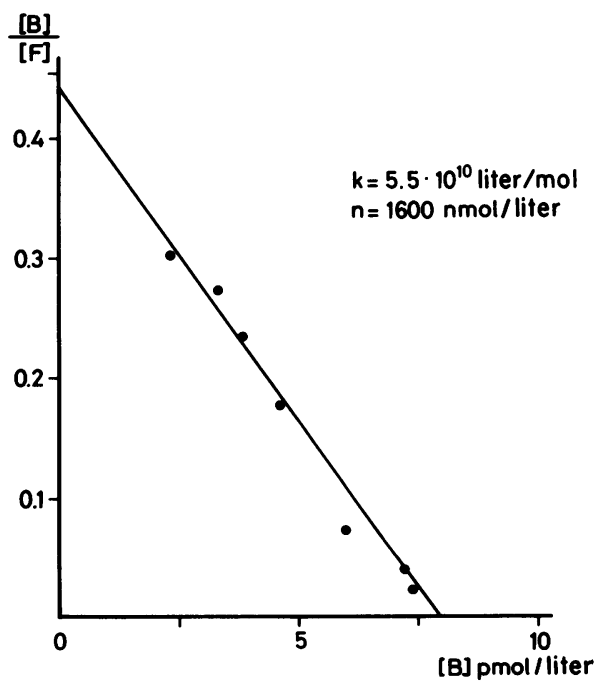

FIGURE 2 Affinity and binding capacity of antigen-stripped antiserum. Antiserum 371-VII was treated several times with guanidine and urea at acid $\mathrm{pH}$ and subjected to gel filtration on Ultrogel 44 columns. The resulting antibody preparation (stage II) did not contain detectable bound glucagon. The binding constants of the antibodies were calculated from the Scatchard plot (see legend to Fig. 1). duced glucagon took place after the administration of antiserum: (a) The capacity and avidity of the dose of antiserum injected in experiments 1-5 appear adequate. The total binding capacity (1.17 $\mathrm{nmol})$ represents more than one-third of the total content of glucagon in the rat pancreas (3 nmol) (5). Even if only the low capacity, high affinity class of antibodies is taken into account, the capacity $(0.27 \mathrm{nmol}$ per rat) is considerably larger than the total glucagon production over $60 \mathrm{~min}$ of the moderately stimulated rat pancreas $(0.032-0.052 \mathrm{nmol} / \mathrm{h})$ (26). Furthermore, the affinity for glucagon antibodies $\left(5.7 \times 10^{10}\right.$ liters $\left./ \mathrm{mol}\right)$ is much higher than that reported for the hepatic glucagon receptor of the rat $\left(2.5 \times 10^{8} \mathrm{liters} / \mathrm{mol}\right)(27)$, favoring binding of circulating glucagon to antibody rather than to the target organ receptor.

(b) Because the antigen-antibody reaction is reversible and obeys the law of mass action, one cannot with this technique expect to bind (neutralize) all of the circulating glucagon in the rat. Rather the efficiency of the technique will depend on how low the resulting concentration of free (= not bound to antibody) glucagon will be. In our experiments, the concentration of free glucagon in antiserum-treated rats was one-third of the concentration of glucagon in control rats. This was determined $75 \mathrm{~min}$ after the injection of antiserum, during which period the rats had been strenuously exercised for $60 \mathrm{~min}$. Considering the very high concentrations of bound glucagon found at the same time, the concentration of free glucagon is in fact quite close to the value one would expect theoretically, according to the law of mass action. ${ }^{1}$

(c) The described distribution between free and bound glucagon is supposed to represent the true distribution in mixed cardiac blood and, accordingly, in the arterial blood under steady-state conditions. It is therefore reasonable to conclude that in antiserumtreated rats substantially reduced concentrations of free glucagon reach the liver, the principal site of action of glucagon. It was, however, of interest to study the time-course of binding, to estimate the likelihood of neutralization of newly released glucagon on its way from the pancreas to the liver. Again we chose to study this under the least favorable conditions, namely, with the use of arterial plasma from rats, which, $15 \mathrm{~min}$ after the administration of antiserum, had been exercised

\footnotetext{
${ }^{1}$ Assuming that the high affinity antibody class governs the reaction in very dilute solutions, we get, according to the law of mass action, $K=[A g A b] /\left[\mathrm{Ag}^{-}\right]\left[A b^{-}\right] 5.7 \times 10^{10}$ liter $/ \mathrm{mol}$ $=10.2 \times \mathrm{nmol} / \mathrm{liter} /($ free hormone $) \times 10.8 \times \mathrm{nmol} / \mathrm{liter}$, where the value for the concentration of antibody is derived from the experimentally determined binding capacity in $300 \mu \mathrm{l}$ rat plasma at 1,500 times dilution. Solved for "free hormone," we get $16.5 \mathrm{pmol} / \mathrm{liter}$. The value of the equilibrium constant is probably too high, being determined at $4^{\circ} \mathrm{C}$, and not at $37^{\circ} \mathrm{C}$. A lower value of $K$ would have resulted in higher concentrations of free hormone.
} 
for $60 \mathrm{~min}$. Even then, there was still a high concentration of free antibody binding sites in the plasma. The plasma samples were incubated at $37^{\circ} \mathrm{C}$ with $150 \mathrm{fmol}$ of glucagon, simulating an endogenous production of glucagon resulting in a calculated increase in the concentration of free glucagon of $300 \mathrm{pmol} / \mathrm{liter}$. After $10 \mathrm{~s}$ $25 \%$ of the added glucagon was antibody-bound (corrected for nonspecific precipitation [24]) and after $120 \mathrm{~s}$ $69 \%$ was bound. It is thus conceivable that even late in the exercise experiments a substantial neutralization of glucagon took place during the sequence of events from the extrusion of the molecules from the alpha cell until their arrival at the liver cell membrane.

(d) The effect of exogenous glucagon administered in a dose $(30 \mathrm{pmol} / \mathrm{kg})$ which in control rats produced significant hyperglycemia was neutralized by the antiserum treatment. The lack of increase of blood glucose concentration in antiserum-treated rats was accompanied by lower insulin and glycerol concentrations in comparison with control serum-treated rats.

Nevertheless, all the above arguments can be regarded as only circumstantial evidence for the efficiency of the antiserum treatment. Another approach would consist of the demonstration of abolition of an expected effect of endogenous glucagon. We recently reported the results of such experiments (12). It was shown that the administration of antiserum significantly reduced the depletion of hepatic glycogen stores in fed rats forced to swim compared to control rats, an effect believed to be mediated by neutralization of the exercise-induced increase in glucagon secretion.

Although all of the findings discussed above thus indicated that an extensive and rapid neutralization of endogenously released glucagon will take place after the administration of a potent antiserum, we were not able to demonstrate a hypoglycemic effect of the treatment in 3-h-fasted rats. Nor did antiserum treatment lead to hypoglycemia in 10- and 48-h-fasted rats, although it might have been expected that maintained or increased concentrations of glucagon in these rats would be essential for the maintenance of increased gluconeogenesis.

Adrenergic mechanisms which participate in the control of hepatic glucose-production might have compensated the lack of glucagon-mediated glucose production $(28,29)$. But antiserum treatment was also ineffective in adrenalectomized rats and in rats that had a combined chemical sympathectomy and adrenomedullectomy.

It was then possible that the reduction of the concentration of free glucagon achieved by antiserum treatment was too small to cause detectable signs of glucagon deficiency. On the other hand, it would probably be difficult to lower the concentration of free glucagon further by increasing the amount of injected antiserum, because the enormous amounts of bound glucagon ad- ministered with the antiserum would affect the equilibrium concentrations of the reactants in this reversible reaction. The presence of high concentrations of antibody-bound glucagon in glucagon antisera appears to be the rule rather than the exception (30). In eight antisera examined up till now, the concentrations ranged from 15 to more than $1,000 \mathrm{nmol} / / \mathrm{liter}^{2}{ }^{2}$ Obviously Scatchard analysis of such antisera will yield only apparent binding constants of limited use in experiments of the present type. We therefore tried to strip off the bound glucagon before the injection. The procedure followed was associated with considerable losses of antibody as demonstrated by the falling titers in spite of the unmasking of new binding sites (corresponding to as much as $700 \mathrm{nmol} /$ liter). The overall loss in binding capacity was in the order of $60-70 \%$. Nevertheless, the final preparation had a high binding capacity and avidity, and no bound glucagon could be detected.

However, it was still impossible to demonstrate hypoglycemic effects of the antibody treatment, although in six of eight experiments the resulting concentrations of free glucagon were below the detection limit of the assay (4 pmol/liter). In most of our experiments, the injection of control serum or even saline was associated with increasing concentrations of glucose in blood, suggesting that the technique of administration (anesthesia + intracardial injection + volume expansion) had hyperglycemic effects. This hyperglycemic response was not seen after antiserum treatment, suggesting either that glucagon was involved in the mechanism or that glucagon was in fact responsible for some of the basal glucose production; the hyperglycemic effect of the injection technique would then conceal the hypoglycemic effect of the antiserum. The latter mechanism could, however, not explain the results of the experiments with the 48-h-fasted adrenalectomized rats.

Thus, the present results indicate that the major part of the circulating ethanol-extractable glucagon is of limited significance for the maintenance of euglycemia in the rat or, conversely, the effects of glucagon may readily be compensated for by other mechanisms, e.g. diminished insulin secretion (6). Our results contrast to most of those obtained in experiments with somatostatin (7-11). It was reported that suppression of glucagon secretion inhibited the hepatic glucose production in man and $\operatorname{dog}(8,10)$. Species differences may be of importance, but it should be borne in mind that somatostatin has an extremely wide spectrum of actions and has been reported to alter the in vivo response of the liver to glucoregulatory hormones other than glucagon (31). Furthermore, prolonged infusion of somatostatin leads to hyperglycemia in spite of

${ }^{2}$ Holst, J. J. Manuscript to be published. 
continued suppression of glucagon secretion (32). The mechanism of the initial hypoglycemic effect of somatostatin is therefore not readily apparent. It is also known that the effect of exogenous glucagon on the hepatic production of glucose is evanescent; thus, hyperglucagonemia causes no permanent changes in blood glucose concentrations when maintained by infusion for several days, and does not influence glucose tolerance (32). Thus, the essentiality of normal concentrations of glucagon for the maintenance of blood glucose levels in the basal state remains unproven.

\section{ACKNOWLEDGMENTS}

The expert technical assistance of Rikke Grønholt and Lisbeth Kall is gratefully acknowledged.

The study was supported by grants 512-5266 and 512-3717 from the Danish Medical Research Council, and by grants from Idraettens Forskningsråd and the Novo Research Foundation.

\section{REFERENCES}

1. Moloney, P. J., and M. Coval. 1955. Antigenicity of insulin: diabetes induced by specific antibodies. Biochem. J. 59: 179-186.

2. Wright, P. H. 1961. The production of experimental diabetes by means of insulin antibodies. Am. J. Med. 31: $892-900$.

3. Grey, N., J. E. McGuigan, and D. M. Kipnis. 1970. Neutralization of endogenous glucagon by high titer glucagon antiserum. Endocrinology. 86: 1383-1388.

4. Frohman, L. A., M. Reichlin, and J. E. Sokal. 1970. Immunological and biological properties of antibodies to a glucagon-serum albumin polymer. Endocrinology. 87: 1055-1061.

5. Barling, P., and A. Beloff-Chain. 1973. Studies on the administration of glucagon and insulin antibodies to rats. Horm. Metab. Res. 5: 154-159.

6. Epand, R. M., and R. J. Douglas. 1973. The effect of glucagon antibodies on plasma glucose and insulin levels. Biochim. Biophys. Acta. 320: 741-744.

7. DeVane, G. W., T. M. Siler, and S. S. C. Yen. 1974. Acute suppression of insulin and glucose levels by synthetic somatostatin in normal human subjects. J. Clin. Endocrinol. Metab. 38: 913-915.

8. Alford, F. P., S. R. Bloom, J. D. N. Nabarro, R. Hall, G. M. Besser, D. H. Coy, A. J. Kasting, and A. V. Schally. 1974. Glucagon control of fasting glucose in man. Lancet. II: 974-977.

9. Gerich, J. E., M. Lorenzi, V. Schneider, and P. H. Forsham. 1974. Effect of somatostatin on plasma glucose and insulin responses to glucagon and tolbutamide in man. J. Clin. Endocrinol. Metab. 39: 1057-1060.

10. Cherrington, A. D., J. L. Chiasson, J. E. Liljenquist, A. S. Jennings, U. Keller, and W. W. Lacy. 1976. The role of insulin and glucagon in the regulation of basal glucose production in the postabsorptive dog. J. Clin. Invest. 58: 1407-1418.

11. Dobbs, R., H. Sakurai, H. Sasaki, G. Faloona, I. Valverde, D. Baetens, L. Orci, and R. Unger. 1975. Glucagon: role in the hyperglycemia of diabetes mellitus. Science (Wash. D. C.). 187: 544-547.

12. Galbo, H., and J. J. Holst. 1976. The influence of glucagon on hepatic glycogen mobilization in exercising rats.
Pfluegers Archiv. Gesamte Physiol. Menschen. Tiere 363: 49-53.

13. Holst, J. J., and B. Aasted. 1974. Production and evaluation of glucagon antibodies for radioimmunoassay. Acta Endocrinol. 77: 715-726.

14. Karlson, J., B. Diamant, and B. Saltin. 1971. Muscle metabolites during submaximal and maximal exercise in man. Scand. J. Clin. Lab. Invest. 26: 385-394.

15. Sundby, F., and J. Markussen. 1971. Isolation, crystallization, and aminoacid composition of rat glucagon. Horm. Metab. Res. 3: 184-187.

16. Holst, J. J. 1977. The interactions of the glucagon receptor of liver cell membranes with pancreatic and gut type glucagons. In Glucagon: Its Role in Physiology and Clinical Medicine. P. P. Foa, J. S. Bajaj, and N. L. Foa, editors. Springer-Verlag New York Inc., New York. 287-303.

17. Heding, L. G. 1971. Radioimmunological determination of pancreatic and gut glucagon in plasma. Diabetologia. 7: 10-19.

18. Jørgensen, K. H., and U. D. Larsen. 1972. Purification of ${ }^{125}$ I-glucagon by anion exchange chromatography. Horm. Metab. Res. 4: 223-224.

19. Albano, J. D. M., R. P. Ekins, G. Maritz, and R. C. Turner. 1972. A sensitive, precise radioimmunoassay of serum insulin relying on charcoal separation of bound and free hormone moieties. Acta Endocrinol. 70: 487-509.

20. Heding, L. G. 1972. Determination of total serum insulin (IRI) in insulin-treated diabetic patients. Diabetologia. 8: 260-266.

21. Scatchard, G. 1949. The attractions of proteins for small molecules and ions. Ann. N. Y. Acad. Sci. 51: 660-672.

22. Siegel, S. 1956. Nonparametric statistics for the behavioural sciences. McGraw-Hill Kogakusha Ltd., Tokyo.

23. Rosenthal, H. E. 1967. A graphic method for the determination and presentation of binding parameters in a complex system. Anal. Biochem. 20: 525-532.

24. Orskov, H., and K. Seyer-Hansen. 1974. Measurement of and correction for incubation damage in radioimmunoassay. Eur. J. Clin. Invest. 4: 207-211.

25. Thoenen, H., and J. P. Tranzer. 1973. The pharmacology of 6-hydroxydopamin. Annu. Rev. Pharmacol. 13: 169-180.

26. Luyckx, A. 1974. Etude de la sécrétion de l'insulin et du glucagon. Faculté de Médecine, Université de Liege, Liege. 122.

27. Rodbell, M., H. M. J. Kraus, S. L. Pohl, and L. Birnbaumer. 1971. The glucagon-sensitive adenyl cyclase system in plasma membranes of rat liver. J. Biol. Chem. 246: 1861-1871.

28. Edwards, A. V. 1972. The hyperglycaemic response to stimulation of the hepatic sympathetic innervation in adrenalectomized cats and dogs. J. Physiol. (Lond.). 220: 697-710.

29. Edwards, A. V., and M. Silver. 1972. Comparison of the hyperglycaemic and glycogenolytic responses to catecholamines with those to stimulation of the hepatic sympathetic innervation in the dog. J. Physiol. (Lond.). 223: 571-593.

30. Heding, L. G. 1972. Immunological properties of pancreatic glucagon. In Glucagon, Molecular Physiology, Clinical and Therapeutic Implications. P. J. Lefebvre and R. H. Unger, editors. Pergamon Press Ltd., Oxford. 187-200.

31. Saccá, L., R. Sherwin, and P. Felig. 1977. Somatostatin alters the hepatic response to glucagon and epinephrine in vivo independent of insulin and glucagon availability. Diabetologia. 13: 428-429.

32. Felig, P., J. Wahren, R. Sherwin, and R. Hendler. 1976. Insulin, glucagon, and somatostatin in normal physiology and diabetes mellitus. Diabetes. 25: 1091-1099. 